\title{
MODAL SOSIAL DALAM PEMBANGUNAN
}

\author{
Oleh. \\ Anyualatha Haridison ${ }^{1}$
}

\begin{abstract}
ABSTRAK
Tulisan ini ingin mengeksplorasi konsepsi modal sosial dalam pembangunan, baik itu sumber, bentuk dan implikasi modal sosial bagi pembangunan. Modal sosial merupakan : (1) sekumpulan sumberdaya aktual dan potensial; (2) entitasnya terdiri-dari atas beberapa aspek dari struktur sosial, dan entitas-entitas tersebut memfasilitasi tindakan individu-individu yang ada dalam struktur tersebut; (3) asosiasi-asosiasi yang bersifat horisontal; (3) kemampuan aktor untuk menjamin manfaat; (4) informasi; (5) norma-norma;

(6) nilai-nilai; (7) resiprositas; (8) kerjasama; (9) jejaring.

Modal sosial sangat dibutuhkan dalam pembangunan, baik itu pembangunan manusia dan sosial, pembangunan ekonomi, dan pembangunan politik. (1) Pembangunan manusia dan sosial diketahui bahwa Modal sosial dapat meningkatkan kesadaran individu tentang banyaknya peluang yang dapat dikembangkan untuk kepentingan masyarakat, misalnya kemampuan untuk menyelesaikan kompleksitas berbagai permasalahan bersama, mendorong perubahan yang cepat di dalam masyarakat, menumbuhkan kesadaran kolektif untuk memperbaiki kualitas hidup dan mencari peluang yang dapat dimanfaatkan untuk kesejahteraan. (2) Dalam pembangunan ekonomi modal sosial sangat tinggi berpengaruh terhadap perkembangan dan kemajuan berbagai sektor ekonomi. Perkembangan ekonomi yang sangat tinggi di Asia Timur yang dijalankan pelaku ekonomi Cina dilakukan melalui koneksi-koneksi kekeluargaan dan kesukuan, pola ini mendorong pembentukan jaringan rasa percaya (networks of trust) yang dibangun melewati batasbatas keluarga, suku, agama, dan negara. (3) Modal Sosial yang tinggimembawa dampak pada tingginya partisipasi masyarakat sipil dalam berbagai bentuknya. Akibat positif yang dihasilkan adalah pemerintah akan memilki akuntabilitas yang lebih kuat Tingginya modal sosial akan mendorong efektifitas pemerintahan, beragam determinan memungkinkan negara berfungsi secara lebih efektif dan memiliki legitimasi.
\end{abstract}

Kata Kunci : Modal Sosial, Pembangunan, trust.

Terminologi modal sosial [atau lebih dikenal dengan: social capital] digunakan secara berbeda-beda tergantung dari lingkup studi. Dalam perspektif ilmu politik, sosiologi dan antropologi umumnya pengertian modal sosial merujuk pada norma-norma, jejaring dan organisasi-organisasi melalui mana masyarakat memperoleh akses terhadap kekuasaan dan berbagai sumberdaya, yang merupakan peralatan yang memungkinkan pengambilan keputusan dan penyusunan kebijakan. Bagi kalangan ekonom, terutama pada tingkatan mikro-ekonomi, modal sosial dipandang terutama dalam arti kemampuannya untuk memperbaiki berfungsinya pasar. Sedangkan pada aras makro-ekonomi, para ekonom mempertimbangkan modal sosial terkait dengan bagaimana institusi-institusi, kerangka kerja berdasarkan tata aturan, dan peran pemerintah dalam organisasi produksi mempengaruhi penampilan makro-ekonomi.

Dalam tulisan ini, modal sosial akan dilihat dalam lingkup paradigma pembangunan dan tentunya pembahasan ini akan memiliki sejumlah keterkaitan dengan lingkup studi, baik itu studi politik, sosiologi, ekonomi dan antropologi. Pembahasan ini dibagi menjadi : (1) Pengertian modal sosial; (2) Sumber-sumber modal sosial; (3) Bentuk-bentuk modal sosial; (4) Modal Sosial dan Pembangunan.

\section{PENGERTIAN MODAL SOSIAL}

Menurut Bourdieu (Jenkins, 2004) modal sosial adalah sekumpulan sumberdaya aktual atau potensial yang terkait dengan pemilikan suatu jejaring yang tahan lama dari hubungan-hubungan yang sudah terlembagakan yang berawal dari pengenalan dan pengakuan yang saling menguntungkan.

Sedangkan bagi Coleman (1990) modal sosial dilihat berdasarkan fungsinya, yang bukan merupakan entitas tunggal tetapi terdiri dari berbagai entitas yang berbeda-beda, dengan dua karakteristik umum, yakni: (1) semuanya terdiri-dari atas beberapa aspek dari struktur sosial, dan (2) entitas-entitas tersebut memfasilitasi tindakan individu-individu yang ada dalam struktur tersebut. Seperti bentuk modal lainnya, modal sosial bersifat

\footnotetext{
${ }^{1}$ Staf Pengajar Pada Fakultas Ilmu Sosial dan Politik Universitas Palangka Raya
} 
produktif, yang memungkinkan pencapaian beberapa tujuan yang tidak dapat dicapai tanpa keberadaannya. Seperti modal fisik dan modal manusia, modal sosial tidak sepenuhnya dapat ditukar, tetapi dapat ditukar terkait dengan aktivitas-aktivitas tertentu. Bentuk modal tertentu yang bernilai untuk memudahkan beberapa tindakan bisa jadi tidak berguna atau merugikan orang lain. Tidak seperti modal lainnya, modal sosial melekat pada struktur relasi di antara orang dan kalangan orang.

Putnam (1993) mendefinisikan modal sosial adalah suatu kumpulan dari asosiasiasosiasi yang bersifat horisontal di antara orang-orang yang mempunyai pengaruh terhadap produktivitas dari masyarakat setempat. Asosiasi-asosiasi yang dimaksud, termasuk jejaring dari pertalian warga masyarakat (civic engagement) dan norma-norma sosial. Asumsi yang mendasari konsep Putnam adalah: (1) jejaring dan norma-norma yang secara empiris saling terkait; dan (2) jejaring dan norma-norma dimaksud mempunyai konsekuensi-konsekuensi ekonomi yang penting. Oleh sebab itu, ciri kunci dari modal sosial sebagaimana definisi Putnam adalah modal sosial memfasilitasi koordinasi dan kerja sama bagi keuntungan bersama (timbal balik) dari para anggota suatu asosiasi.

Menurut Portes (1998) modal sosial adalah kemampuan dari para aktor untuk menjamin manfaat dengan bertumpu pada keanggotaan dalam jejaring sosial dan strukturstruktur sosial lain. Sedangkan menurut Woolcock (1998) modal sosial adalah derajat kohesi sosial yang ada dalam komunitas. Ia mengacu pada proses-proses antar orang yang membangun jejaring, norma-norma, dan social trust, dan memperlancar koordinasi dan kerjasama yang saling menguntungkan.

Kemudian Lang \& Hornburg (1998) berpendapat bahwa modal sosial umumnya merujuk pada ketersediaan rasa saling percaya di dalam masyarakat (stocks of sosial trust), norma-norma, dan jejaring yang dapat dimanfaatkan masyarakat dalam rangka menyelesaikan persoalan-persoalan bersama. Fukuyama (1995) mengkonsepsikan modal sosial sebagai suatu norma informal yang mendorong kerjasama yang saling menguntungkan.

Dari pandangan beberapa ahli tentang konsepsi modal sosial di atas, maka dapat disimpulkan bahwa modal sosial adalah : (1) sekumpulan sumberdaya aktual dan potensial; (2) entitasnya terdiri-dari atas beberapa aspek dari struktur sosial, dan entitas- entitas tersebut memfasilitasi tindakan individu-individu yang ada dalam struktur tersebut;

(3) asosiasi-asosiasi yang bersifat horisontal; (3) kemampuan aktor untuk menjamin manfaat; (4) informasi; (5) norma-norma; (6) nilai-nilai; (7) resiprositas; (8) kerjasama; (9) jejaring.

\section{SUMBER-SUMBER MODAL SOSIAL}

Teori yang secara memuaskan mengidentifikasikan mekanisme produksi, pemeliharaan dan pertumbuhan modal sosial, hingga kini masih belum memadai. Pantoja (2000) menyebutkan bahwa jika modal sosial didekati semata-mata dalam terma-terma struktural, jika dioperasionalisasi dalam keanggotaan misalnya, terdapat kecenderungan untuk menganggap bahwa keanggotaan tersebut di dalam dirinya sendiri adalah yang memproduksi modal sosial. Juga terlalu menganggap bahwa asosiasi adalah yang menyediakan modal sosial bagi individu dan kelompok.

Suatu kesulitan yang nyata adalah bahwa banyak interaksi dan relasi formal dan informal di antara anggota-anggota suatu masyarakat dapat memperkuat modal sosial, meskipun spektrum dari interaksi yang dimaksud tidak sepenuhnya bisa diobservasi (Stolle and Rochon, 1998).

Putnam (1993) menilai bahwa rasa saling percaya (trust) adalah suatu komponen yang penting dari modal sosial. Umumnya analisis Putnam difokuskan pada trust antar individu (interpersonal trust), meskipun seperti yang dikatakan Williamson (1993) masih ada beberapa trust yang juga relevan, dan membedakan trust ke dalam tiga tipe, yaitu calculative trust, personal trust, dan institutional trust.

Kebanyakan modal sosial dapat dipertimbangkan sebagai sumberdaya bersama. Meskipun aktor-aktor sosial yang spesifik seperti organisasi bisnis atau asosiasi sukarela 
dapat menciptakan modal sosial, ia juga dapat diproduksi atau dihancurkan oleh aktivitasaktivitas lainnya. Kebutuhan dan biaya untuk memproduksi modal sosial, tidak secara universal sama. Kapasitas civil society secara umum untuk menghasilkan [dan juga menghancurkan] modal sosial, dipengaruhi dengan banyak cara yang melalui konteks sosial, politik dan ekonomi. Dalam kaitan ini, Bourdieu (2004) mengatakan bahwa kehadiran dan kepadatan jejaring-jejaring dari berbagai koneksi dan dari asosiasi warga, bukanlah suatu kondisi sosial yang terjadi begitu saja.

Salah satu isu utama yang perlu dipegang adalah bagaimana social trust di antara masyarakat kurang mampu mempunyai pengetahuan yang intim di antara sesamaberkembang dan dipelihara di dalam masyarakat. Menurut dugaan, manfaat yang krusial dari rasa saling percaya antar orang perorangan ditingkatkan oleh keanggotaan asosiasional yang membantu pengembangan masyarakat dimana berbagai macam kerjasama dimungkinkan terkait dengan adanya suatu generalized social trust. Generalized social trust ini diharapkan untuk berkembang melewati batas-batas kekerabatan dan pertemanan, bahkan melewati hubungan perkenalan.

Bagi Putnam (1993) trust mempunyai dua sumber, yakni: (1) norma-norma resiprositas; (2) jejaring dari pertalian warga. Menurut Granovetter (1985), trust di dalam masyarakat muncul terutama karena relasi-relasi sosial. Sebaliknya, bagi Levi (1998) trust yang muncul pada asosiasi-asosiasi tingkat menengah dapat saja tidak mencukupi untuk menghasilkan generalized social trust, sementara itu, institusi-institusi negara dapat pula menyediakan dasar bagi generalized trust.

Menurut Levi (1998) trust dari pendekatan perilaku dapat didefinisikan sebagai suatu tindakan yang diambil dalam situasi yang beresiko, tetapi terdapat suatu alasan untuk memercayai seseorang yang ingin dipercaya. Sumber bagi kepercayaan ini bervariasi (pengetahuan aktual, sanksi-sanksi institusional, keyakinan terhadap keyakinan seseorang, dan lain-lain), tetapi semuanya relatif memerlukan pengorbanan kecil terhadap individu yang diputuskan untuk dipercaya. Tentunya, mekanisme-mekanisme kognitif akan memainkan peran dalam hal ini.

Bagi Levi (1998) trust adalah human passion dan modality of human action. Sebagaimana human passion, trust merepresentasi keyakinan yang terdapat dalam harapanharapan sehubungan dengan perhatian-perhatian yang ramah dari berbagai agen sosial. Sebagai modality of action, trust selalu bersifat strategis, dan memerlukan kurang lebih kebijakan yang diputuskan secara sadar untuk sepakat dengan kebebasan orang lain. Menurut Pantoja, pandangan ini terkait dengan apa yang disebut oleh Williamson tentang personal trust dan calculative trust.

\section{BENTUK-BENTUK MODAL SOSIAL}

Nilai dari konsep modal sosial terletak pertama-tama dalam kenyataan bahwa modal sosial memperkenalkan aspek-aspek tertentu dari struktur sosial berdasarkan fungsifungsinya. Nilai ini merupakan sumberdaya yang dapat digunakan oleh para aktor untuk mencapai kepentingan-kepentingannya. Dalam konteks ini, konsep modal sosial memungkinkan pemanfaatan sumberdaya-sumberdaya dan menunjukkan bagaimana sumberdaya-sumberdaya tersebut dapat saling dikombinasikan untuk menghasilkan derajat perilaku yang berbeda. Menurut Coleman (2011) ada enam bentuk dari modal sosial, yaitu : (1) kewajiban dan ekspektasi; (2) saluran informasi; (3) norma dan sanksi efektif; (4) relasi wewenang; (5) organisasi sosial yang dapat disesuaikan; (6) organisasi yang disengaja.

Pertama, Kewajiban dan Ekspektasi. Jika A melakukan sesuatu untuk B dan percaya bahwa B akan membalasnya pada masa depan, hal ini menciptakan ekspektasi di pihak A dan kewajiban di pihak B untuk memelihara kewajiban tersebut. Kewajiban ini dapat dipahami sebagai slip kredit yang dipegang oleh A. Slip kredit yang akan ditebus dengan beberapa tindakan dati B. Jika A memegang sejumlah besar slip kredit ini dari sejumlah orang yang memiliki relasi dengannya, maka ada analogi langsung dengan modal uang: slip kredit merupakan sejumlah besar kredit yang dapat ditarik A jika diperlukan- kecuali kalau pemberian kepercayaan tersebut tidak bijaksana, dan slip tersebut menggambarkan 
piutang sanksi yang tidak akan dilunasi. Dalam beberapa struktur sosial dikatakan bahwa orang-orang selalu melakukan sesuatu untuk satu sama lain. Ada sejumlah besar slip kredit ini yang belum dilunasi, seringkali pada kedua sisi relasi (karena slip kredit ini seringkali tidak dapat ditukarkan dalam bidang aktivitas berbeda maka slip kredit dari B yang dipegang oleh A dan slip kredit A dipegang oleh B tidak digunakan sepenuhnya untuk saling melunasi). Ada dua elemen kritis pada bentuk modal sosial ini: tingkat kredibilitas lingkungan sosial, yang berarti bahwa kewajiban akan dilunasi dan tingkat kewajiban aktual tersebut dipegang. Struktur-struktur sosial berbeda pada kedua dimensi ini, dan para pelaku dalam struktur tertentu berbeda dengan pelaku dalam struktur lain. Menurut Coleman, perbedaan dalam struktur sosial dalam kedua dimensi yang disebutkan di atas, muncul karena beberapa alasan : (1) ada perbedaan dalam kebutuhan-kebutuhan aktual yang dimiliki seseorang untuk membantu di tengah ketersediaan sumber-sumber bantuan lainnya; (2) tingkat kemakmuran mengurangi bantuan yang diperlukan oleh orang lain; (3) perbedaan dalam kultur terkait dengan kecenderungan untuk memberikan bantuan dan meminta bantuan dalam jaringan-jaringan sosial yang tertutup.

Kedua, Saluran Informasi. Bentuk modal sosial yang penting adalah potensi informasi yang melekat pada relasi-relasi sosial. Informasi penting untuk mendasari tindakan, tetapi akuisisi informasi merugikan. Informasi sekurang-kurangnya memerlukan perhatian, yang selalu cepat diberikan. Alat yang dapat digunakan untuk mendapatkan informasi adalah penggunaan relasi sosial yang dipertahankan untuk tujuan-tujuan lain. Misalnya seorang ilmuwan sosial yang tertarik penelitiannya menjadi terdepan di bidang yang terkait dapat menggunakan interaksinya setiap hari dengan kolega yang juga melakukan penelitian, jika ia dapat mengandalkan kolega yang terdepan di bidangnya.

Ketiga, Norma dan Sanksi Efektif. Coleman menegaskan bahwa ketika norma efektif terbentuk, norma tersebut menjadi bentuk modal sosial yang kuat tetapi kadang rapuh. Norma-norma preskriptif yang merupakan bentuk modal sosial sangat penting dalam kolektivitas adalah norma yang membuat seseorang melepaskan kepentingan diri sendiri untuk bertindak demi kepentingan kolektivitas. Norma tersebut diperkuat dengan dukungan sosial, status, kehormatan, dan penghargaan lain.

Keempat, Relasi Wewenang. Jika pelaku A mengalihkan hak kendali beberapa tindakan kepada pelaku lain, B, maka B menyediakan modal sosial dalam bentuk hak kendali tersebut. jika sejumlah pelaku mengalihkan hak kendali yang sama pada B, maka B menyediakan kumpulan modal sosial yang besar, yang dapat dikonsentrasikan pada beberapa aktivitas. Pengalihan kendali ini tentu saja meletakkan kekuasaan yang besar ke tangan B.

Kelima, Organisasi Sosial yang Dapat Disesuaikan. Organisasi yang didirikan untuk satu rangkaian tujuan juga dapat membantu tujuan lainnya, karenanya menjadi modal sosial yang dapat digunakan. Misalnya sekolempok mahasiswa radikal di Korea Selatan digambarkan sebagai kelompok mahasiswa yang berasal dari sekolah lanjutan atau gereja yang sama. Dalam kasus ini juga organisasi didirikan untuk satu tujuan dapat disesuaikan dengan tujuan lain, menjadi modal sosial penting untuk individu-individu yang telah menyediakan sumber organisasi.

Keenam. Organisasi yang Disengaja. Penggunaan konsep modal sosial tergantung pada keberadaan hasil sampingan aktivitas yang diikutsertakan untuk tujuan-tujuan lain. Bagian selanjutnya akan menunjukkan mengapa demikian, mengapa sering ada investasi modal sosial kecil atau tidak langsung. Namun ada bentuk-bentuk modal sosial yang merupakan hasil langsung investasi dari para pelaku yang bertujuan mendapat keuntungan dari investasinya. Contoh paling menonjol adalah sebuah organisasi yang didirikan oleh pemilik modal uang untuk tujuan mendapat penghasilan. Dalam mendirikan organisasi semacam itu, seorang kapitalis mengubah modal uang menjadi modal fisik dalam bentuk bangunan dan peralatan, modal sosial dalam bentuk organisasi terdiri atas beberapa posisim dan modal manusia dalam bentuk orang-orang yang mengisi posisi tersebut.

Pantoja (2000) membedakan bentuk-bentuk modal sosial sebagai berikut : (1) hubungan-hubungan keluarga dan kekerabatan, meliputi: rumah tangga, keluarga luas, atau klien berdasarkan pada kuatnya pertalian darah dan afinitas; (2) jejaring sosial atau 
kehidupan asosiasional, meliputi: jejaring yang dimiliki individu, kelompok dan organisasiorganisasi yang menghubungkan individu dari keluarga-keluarga yang berbeda, atau kelompok-kelompok yang memiliki kesamaan aktivitas untuk berbagai maksud; (3) keterkaitan lintas sektor, termasuk jejaring yang menghubungkan organisasi- organisasi dari berbagai sektor di dalam masyarakat (LSM, organisasi akar rumput, perwakilan pemerintah, perusahaan swasta) yang memungkinkan kombinasi sumberdaya dan tipe pengetahuan yang berbeda-beda guna menemukan pemecahan masalah dari masalahmasalah yang kompleks. Bentuk modal sosial ini menyediakan artikulasi antara asosiasi dan organisasi yang bersifat horisontal dan vertikal; (4) norma-norma dan nilai- nilai sosial, mencakup kepercayaan budaya yang luas dan pengaruh kepercayaan yang dimaksud terhadap berfungsinya masyarakat secara umum. Norma-norma dan nilai-nilai mendukung bentuk-bentuk modal sosial lainnya sekaligus merepresentasi bentuk paling umum dan paling sulit dari modal sosial.

\section{IMPLIKASI MODAL SOSIAL DALAMPEMBANGUNAN}

Terdapat bukti yang terus berkembang bahwa modal sosial mempunyai pengaruh yang kuat terhadap hasil-hasil pembangunan, termasuk pertumbuhan, keadilan, dan pengentasan kemiskinan (Grootaert, 1996). Berbagai asosiasi dan institusi menyediakan suatu kerangka kerja informal untuk berbagi informasi (sharing information), mongkoordinasikan aktivitas-aktivitas (coordinating activities), dan membuat keputusankeputusan bersama (making collective decision).

(1) Sharing information : Institusi-institusi formal dan informal dapat membantu mencegah kegagalan pasar terkait dengan ketidakcukupan dan ketidaktepatan informasi. Para agen pelaku ekonomi sering membuat keputusan-keputusan yang tidak efisien karena kekurangan informasi yang diperlukan, atau karena salah satu agen memperoleh keuntungan dengan cara menyampaikan informasi yang tidak tepat kepada yang lainnya. Dalam kondisi yang lain, keputusan-keputusan yang optimal mungkin sulit dilakukan karena ketidakpastian dan respons dari para agen lainnya terhadap ketidakpastian yang dimaksud. Dalam konteks ini institusi-institusi dapat membantu menyebarluaskan informasi yang cukup dan tepat, yang memungkinkan para pelaku pasar untuk membuat keputusan-keputusan yang cocok dan efisien. Ketidakpastian dalam pasar modal, dapat diminimalisasi pula melalui ketentuan hukum dan berfungsinya sistem peradilan dengan baik, sehingga dapat mendukung atau memperkuat hubungan-hubungan kontaktual yang terjadi dalam pasar.

(2) Coordinating activities. Perilaku yang tidak terkoordinasi atau petualangan yang dilakukan oleh para agen ekonomi, dapat pula menyebabkan kegagalan pasar. Merujuk pada pengalaman proyek-proyek, tampaknya perilaku dimaksud muncul sebagai akibat kurangnya kekuatan institusi sosial baik formal maupun informal dalam rangka mengatur kesepakatan secara adil. Institusi-institusi dimaksud dapat mengurangi perilaku petualangan melalui pengembangan kerangka kerja dalam mana para individu dapat saling berinteraksi sehingga memperkuat rasa saling percaya di antara para anggota.

(3) Making collective decisions. Pembuatan keputusan bersama adalah kondisi yang diperlukan bagi penyediaan barang-barang publik dan pengelolaan eksternalitas pasar. Tidak berbeda dengan pemerintah, asosiasi-asosiasi lokal dan yang bersifat sukarela pun tidak selalu efektif dalam memaksimalkan kemampuan untuk membuat keputusan keputusan bersama. Dalam konteks ini, asosiasi - asosiasi tersebut tidak semata-mata tergantung dari bagaimana mereka mengatasi persoalan information-sharing, tetapi juga pada derajat keadilan yang tersedia. Institusi - institusi lokal umumnya lebih efektif dalam memperkuat kesepakatan bersama dan tindakan kerja sama bilamana aset-aset didistribusikan secara relatif adil dan keuntungan dapat dibagi secara merata. Dengan demikian pada aras lokal, efisiensi dan keadilan berjalan seiring. Pembagian menyediakan suatu insentif untuk memperbaiki koordinasi dalam pengelolaan barang-barang publik, sehingga menambah produkstivitas bagi setiap orang. Selain ekonomi mikro, pasar juga dipengaruhi oleh lingkungan ekonomi makro dan politik ekonomi. Akan tetapi, lingkungan makro dapat pula merusak pengaruh dari modal sosial pada aras lokal. Ketika 
pemerintahan dan sistem peradilan berfungsi dengan baik, dan terdapat kebebasan berekspresi, maka institusi-institusi lokal akan berkembang pesat dan melengkapi fungsifungsi dari institusi-institusi makro. Sebaliknya, ketika tidak berfungsi dengan baik, institusi-institusi lokal akan mencoba untuk menggantikan ketidakberdayaan dimaksud. Dengan demikian, apa yang diperlukan adalah pandangan yang seimbang terhadap peran dari pusat (negara) dan institusi - institusi pada aras lokal.

Dalam banyak hal ketiga konsep yang dikatakan oleh Grootaert (1996) tadi sangat mendukung proses pembangunan sebuah negara. Norma-norma sosial dapat bekerja untuk mengurangi biaya transaksi melalui peningkatan harapan-harapan, aturan-aturan informal dan pemahaman bersama yang memungkinkan orang untuk melakukan interaksi sosial dan bisnis secara efisien. Jejaring yang telah berkembang baik juga bisa mengurangi biaya transaksi. Dalam politik, jejaring yang diciptakan lewat trust dari seseorang kandidat selama menjadi anggota masyarakat akan mengurangi biaya kampanye dibandingkan kandidat yang baru ingin mengangkat elektabilitasnya.

Bertambahnya bentuk-bentuk modal sosial tertentu tampaknya menambah kecepatan penyebaran ide-ide, pengetahuan dan informasi ke seluruh lapisan masyarakat. Secara umum, semakin erat hubungan-hubungan di dalam masyarakat, semakin mudah bagi orang untuk meneruskan informasi dan semakin banyak yang akan memperoleh informasi. Pada lain pihak, beberapa elemen atau manifestasi dari modal sosial terkait dengan kuatnya dinamika kelompok-kelompok masyarakat, yang secara potensial dapat mengurangi aliran informasi ke dalam suatu kelompok dan merintangi terjadinya inovasi- inovasi pembangunan. Hal ini memengaruhi perbedaan pengaruh antara bridging dan bonding social capital. Bridging social capital mencakup keterkaitan lintas kelompok dengan ciri yang berbeda-beda, sedangkan bonding social capital menunjukkan keterkaitan antara orang dengan karakteristik yang sama.

\section{Modal Sosial dan Pembangunan Manusia}

Putnam dalam Hasbullah (2006) menyatakan bahwa bangsa yang memiliki modal sosial tinggi cenderung lebih efisien dan efektif dalam menjalankan berbagai kebijakan untuk mensejahterakan dan memajukan kehidupan rakyatnya. Modal sosial dapat meningkatkan kesadaran individu tentang banyaknya peluang yang dapat dikembangkan untuk kepentingan masyarakat. Dalam konteks pembangunan manusia, modal sosial mempunyai pengaruh yang besar sebab beberapa dimensi pembangunan manusia sangat dipengaruhi oleh modal sosial antara lain, kemampuan untuk menyelesaikan kompleksitas berbagai permasalahan bersama, mendorong perubahan yang cepat di dalam masyarakat, menumbuhkan kesadaran kolektif untuk memperbaiki kualitas hidup dan mencari peluang yang dapat dimanfaatkan untuk kesejahteraan. Hal ini terbangun oleh adanya rasa saling mempercayai, kohesifitas, tindakan proaktif, dan hubungan internal-eksternal dalam membangun jaringan sosial didukung oleh semangat kebajikan untuk saling menguntungkan sebagai refleksi kekuatan masyarakat. Situasi ini akan memperbesar kemungkinan percepatan perkembangan individu dan kelompok dalam masyarakat tersebut. Bagaimanapun juga kualitas individu akan mendorong peningkatan kualitas hidup masyarakat itu berarti pembangunan manusia paralel dengan pembangunan sosial.

\section{Modal Sosial dan Pembangunan Sosial}

Masyarakat yang memiliki modal sosial tinggi akan membuka kemungkinan menyelesaikan kompleksitas persoalan dengan lebih mudah. Dengan saling percaya, toleransi, dan kerjasama mereka dapat membangun jaringan baik di dalam kelompok masyarakatnya maupun dengan kelompok masyarakat lainnya. Pada masyarakat tradisional, diketahui memiliki asosiasi-asosiasi informal yang umumnya kuat dan memiliki nilai-nilai, norma, dan etika kolektif sebagai sebuah komunitas yang saling berhubungan. Hal ini merupakan modal sosial yang dapat mendorong munculnya organisasi-organisasi modern dengan prinsip keterbukaan, dan jaringan- jaringan informal dalam masyarakat yang secara mandiri dapat mengembangkan pengetahuan dan wawasan 
dengan tujuan peningkatan kesejahteraan dan kualitas hidup bersama dalam kerangka pembangunan masyarakat.

Berkembangnya modal sosial di tengah masyarakat akan menciptakan suatu situasi masyarakat yang toleran, dan merangsang tumbuhnya empati dan simpati terhadap kelompok masyarakat di luar kelompoknya. Hasbullah (2006) memaparkan mengenai jaringan-jaringan yang memperkuat modal sosial akan memudahkan saluran informasi dan ide dari luar yang merangsang perkembangan kelompok masyarakat. Hasilnya adalah lahirnya masyarakat peduli pada berbagai aspek dan dimensi aktifitas kehidupan, masyarakat yang saling memberi perhatian dan saling percaya. Situasi yang mendorong kehidupan bermasyarakat yang damai, bersahabat, dan tenteram.

\section{Modal Sosial dan Pembangunan Ekonomi}

Modal sosial sangat tinggi pengaruhnya terhadap perkembangan dan kemajuan berbagai sektor ekonomi. Fukuyama (1999) menunjukkan hasil-hasil studi di berbagai negara yang menunjukkan bahwa modal sosial yang kuat akan merangsang pertumbuhan berbagai sektor ekonomi karena adanya tingkat rasa percaya yang tinggi dan kerekatan hubungan dalam jaringan yang luas tumbuh antar sesama pelaku ekonomi. Hasbullah (2006) memberikan contoh perkembangan ekonomi yang sangat tinggi di Asia Timur yang dijalankan pelaku ekonomi Cina. Usahanya memiliki tingkat kohesifitas yang tinggi karena dilakukan dengan koneksi-koneksi kekeluargaan dan kesukuan, dan pola ini mendorong pembentukan jaringan rasa percaya (networks of trust) yang dibangun melewati batas-batas keluarga, suku, agama, dan negara.

Budaya gotong-royong, tolong menolong, saling mengingatkan antar individu dalam entitas masyarakat desa merefleksikan semangat saling memberi (reciprocity), saling percaya (trust), dan adanya jaringan-jaringan sosial (social networking). Pembangunan industri pada masyarakat dengan modal sosial tinggi akan cepat berkembang karena modal sosial akan menghasilkan energi kolektif yang memungkinkan berkembangnya jiwa dan semangat kewirausahaan di tengah masyarakat yang pada gilirannya akan menumbuhkembangkan dunia usaha. Investor asing akan tertarik untuk menanamkan modal usaha pada masyarakat yang menjunjung nilai kejujuran, kepercayaan, terbuka dan memiliki tingkat empati yang tinggi. Modal sosial, berpengaruh kuat pada perkembangan sektor ekonomi lainnya seperti perdagangan, jasa, konstruksi, pariwisata dan lainnya.

Putnam (2000) menjelaskan mengenai modal sosial dan institusi-institusi demokrasi di wilayah Italia yang berbeda sejak tahun 1970-an. Putnam menemukan bahwa partisipasi warga terkait dengan kinerja pemerintah regional. Kemudian Putnam menemukan gabungan indikator tentang modal sosial di Amerika Serikat yang mempunyai korelasi negatif dengan data tentang penghindaran pajak di seluruh Amerika, yaitu pemenuhan kewajiban pajak tinggi di negara-negara bagian yang mempunyai modal sosial tinggi. Selanjutnya setelah melakukan kontrol terhadap perbedaan-perbedaan antar negara bagian dalam modal sosial. Terlihat pendapatan perkapita, ketidaksamaan pendapatan, komposisi ras, urbanisasi dan tingkat pendidikan, modal sosial merupakan satu-satunya faktor yang ditemukan terkait dengan keberhasilan pemenuhan pajak yang diperkirakan.

\section{Modal Sosial dan Pembangunan Politik}

Modal Sosial yang tinggi, menurut Putnam (2002) membawa dampak pada tingginya partisipasi masyarakat sipil dalam berbagai bentuknya. Akibat positif yang dihasilkan adalah pemerintah akan memilki akuntabilitas yang lebih kuat (Hasbullah, 2006). Tingginya modal sosial akan mendorong efektifitas pemerintahan, beragam determinan memungkinkan negara berfungsi secara lebih efektif dan memiliki legitimasi. Modal sosial tinggi yang dimiliki masyarakat lebih dapat memfasilitasi hubungan antara negara dan rakyat. Hubungan yang baik antara pemerintah dan masyarakat akan menjamin stabilitas politik negara. Di tingkat lokal, modal sosial dapat menjembatani hubungan pemerintah daerah dan masyarakat dalam menyebarkan informasi dan mengimplementasikan programprogram pembangunan. Kepercayaan masyarakat kepada 
pemerintah, keterbukaan pemerintah pada masyarakat, adanya komitmen dan keinginan yang kuat antara pemerintah daerah dan masyarakat untuk membangun, serta adanya partisipasi aktif masyarakat dalam pembangunan akan mendorong terciptanya pembangunan sistem pemerintahan yang baik dimana akuntabilitas dan transparansi pemerintahan berimbang dengan akses dan kontrol masyarakat terhadap pemerintahan. Hal ini juga dapat mendorong demokrasi tumbuh dari bawah dan memungkinkan pembangunan politik tidak hanya pada aras pusat tapi juga aras lokal.

Di samping itu, negara melalui sistem pemerintahan yang baik dapat mendorong menguatnya modal sosial yang mendukung berkembangnya kepercayaan, nilai-nilai, dan norma yang baik dengan menciptakan situasi yang kondusif dalam mempererat jaringjaring sosial di dalam masyarakat dan merangsang tumbuhnya sikap proaktif masyarakat dalam pembangunan. Sebagai contoh, Rice (Putnam, 1993) dalam survei terhadap 114 komunitas di IOWA, Amerika, menemukan beberapa elemen atau indikator dari modal sosial: interpersonal trust, pertalian warga, jejaring dan kesamaan politik. Secara positif dan signifikan berkorelasi dengan dua kinerja pemerintah (ketanggapan dan efektivitas). Hubungan tampak setelah melakukan analisis regresi digunakan untuk mengontrol pendapatan, penyebaran pendapatan, penyebaran usia dan homogenitas ras.

\section{PENUTUP}

Modal sosial merupakan sumberdaya sosial yang dapat dipandang sebagai investasi untuk mendapatkan sumberdaya baru dalam masyarakat. Oleh karena itu modal sosial diyakini sebagai salah satu komponen utama dalam menggerakkan kebersamaan, mobilitas ide, saling kepercayaan dan saling menguntungkan untuk mencapai kemajuan bersama, khususnya pembangunan. Fukuyama (1999) menyatakan bahwa modal sosial memegang peranan yang sangat penting dalam memfungsikan dan memperkuat kehidupan masyarakat modern. Modal sosial merupakan syarat yang harus dipenuhi bagi pembangunan manusia, pembangunan ekonomi, sosial, politik dan stabilitas demokrasi. Berbagai permasalahan dan penyimpangan yang terjadi di berbagai negara determinan utamanya adalah kerdilnya modal sosial yang tumbuh di tengah masyarakat.

\section{Daftar Pustaka}

Coleman, J., 1990. Foundations of Social Theory. Cambridge Mass: Harvard University Press.

Fukuyama F., 1995. Trust: The Social Virtues and The Creation of Prosperity. New York: Free Press.

Fukuyama, Francis. 1999. The End of History and The Last Man: Kemenangan Kapitalisme dan Demokrasi Liberal. Yogyakarta: Penerbit Qalam.

Granovetter, M., 1985. "Economic Action and Social Structure: the Problem of Embeddedness.", American Journal of Sociology.

Grootaert, Christian. 1998, Social Capital : The Missing Link?, The World Bank Social Development Family, Enviromentally, and Socially Sustainable Development Network, Social Capital Initiative, Working Paper No. 3

Hasbullah, Jousairi. 2006. Sosial Capital: Menuju Keunggulan Budaya Manusia Indonesia). Jakarta: MR United Press.

Jenkins, Richard, 2004, Membaca Pikiran Pierre Bourdieu, Yogyakarta: Kreasi Wacana.

Lang, Robert T., dan Steven P. Hornburg, 1998. What is Social Capital and Why Is it important to Public Policy, Housing Policy Debate, Volume 9, Issue 1, Fannie Mae Foundation.

Levi, 1998. Trust and Governance, New York: Russell Sage Foundation Limited. 
Pantoja, Enrique, 2000, Exploring the Concept of Social Capital and Its Relevance for Community-Based Development: The Case of Coal Mining Areas in Orissa, India, The World Bank Social Development Family and Socially Sustainable Development Network, Social Capital Initiative, Working Paper No. 18

Portes, A., 1998. Social Capital: Its Origins and Applications in Modern Sociology. Annual Review of Sociology.

Putnam, R.D. 1993. The Prosperous Community: Social Capital and Public Life. American Prospect, 13, Spring, 35- 42. In Elinor Ostrom and T.K. Ahn. 2003. Foundation of Social Capital. Massachusetts: Edward Elgar Publishing.

Serageldin, Ismail and Christian Grootaert, Defining Social Capital : An Integrating View, dalam Dasgupta, Partha and Ismail. 1999, Social Capital- A Multifaceted Perspective, The World Bank, WashingtonD.C.

Williamson, Oliver E., 1993. —Calculativeness, Trust, and Economic Organization.|JJournal of Law and Economics. 